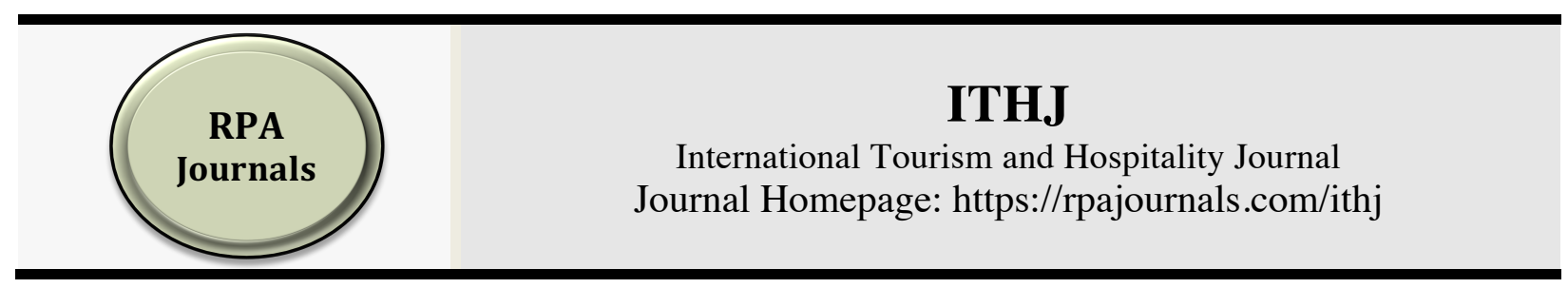

\title{
The Impact of Destination Image on Tourists' Satisfaction and Loyalty: A Case of Egypt
}

\author{
Yasmine Mohsen Elsayeh \\ Faculty of Tourism and Hotel Management \\ Pharos University, Egypt
}

\begin{abstract}
Tourism is an extremely complex field and in order to understand its complexity, none of its components should be left aside. That's why, as many other researchers have done before, the present paper aims to analyse the central element of the entire tourist activity especially the tourist. Based on the impressions, opinions and thoughts of them, we tried to determine to what extent the image of the Egypt as a destination has an impact on the satisfaction and loyalty they have towards that destination. Therefore, this paper represents a market research aimed at evaluating the image of Egypt as tourist destination as perceived by tourists and to what extent their satisfaction and loyalty such as intentions to revisit/recommend can be influenced by it. The sample included 20 visitors, who were contacted via social networks. Upon review of the responses, it was found out that there are a number of important elements for the tourists, while other aspects have a slightly influence on their satisfaction and loyalty. The conclusions of this research should be taking into account by all the stakeholders involved in the development and promotion of tourist destinations in Egypt.
\end{abstract}

Keywords: Destination Image, Tourists' Satisfaction, Tourists' Loyalty, Egypt

*Corresponding author: Yasmine Mohsen Elsayeh; E-mail: yasmineelsayeh@gmail.com

DOI: https://doi.org/10.37227/ithj-2020-02-28

\section{Introduction}

Due to the fact that tourism is one of the most dynamic sectors of the economy, there are plenty of researches aimed to analyze and explain the entire phenomenon, its causes as well as its effects. Some of these factors are the reasons and motivations that make people travel (Herle, 2018). Tourists are the ones who search, analyze, buy, visit and give feedback to everything that the tourism industry is offering them in order to satisfy their needs. So, this industry needs to keep up with new trends to ensure its success and performance, as modern tourists are looking not only for a bed and some food but for a real experience when deciding to travel. Given the fact that this experience is gained at a tourist destination, many theorists have tried to define both the tourist destination itself and other essential aspects that any destination should take into account in order to compete with other destinations. For example, one of the most competitive advantages a destination can have is a strong destination image, Researches are showing that image is becoming one of the key factors in destination choice (Schneider \& Somnez, 1999; Alcañiz et al., 2001; Beerli \& 
Martin, 2004; Chen \& Tsai, 2007; Lee, 2009; Wang and Hsu, 2010) and the destination with strong and positive image has higher probability of being chosen by the tourists (Beerli \& Martin, 2004; Lee, 2009), Taking into consideration the intangibility of tourism product, image is becoming the only mean that potential tourist has in comparation and selection of destination (O'Leary \& Deegan, 2005) So, image plays a fundamental role in the success of tourism destinations since it strongly influences the choice of a destination and tourism satisfaction. Therefore, destination image and the factors influencing it are becoming extremely important for good positioning of destinations on the international tourism market and can improve the competitive advantages of a destination, if it is positive. By understanding the causal relationships between destination image, tourist satisfaction and loyalty, Tourism destination managers should be better able to create an appealing image Therefore; this study examined the relationships between destination image and tourism satisfaction to achieve loyalty in Egypt.

\section{Literature Review}

\section{Destination Image}

The image is a fundamental element in the promotion of tourism destinations, since what differentiates one destination from another is key to its success (Carballo et al., 2015). The importance of this concept has led to a growing researches on tourism destinations (Gallarza, Saura \& Garc, 2002) Destination image represented a real subject of interest for both practitioners and academics over time and since the '90s it has been studied in correlation with the destination branding (Almeyda \& Babu, 2017).

One of the first studies on image formation was that by Gunn (1972), which looked at only two dimensions of the formation process: the organic image and the induced image. The organic image is understood as that arising from non-commercial or uncontrolled information sources, such as the opinions of friends, magazines, newspapers, news, reports, etc. In contrast, the induced image is that proffered by commercial information sources, i.e., marketing efforts of various commercial agents to publicize a destination (Alcocer \& Ruiz, 2019).

Destination image was found to have an impact on many aspects such as tourist destination satisfaction, loyalty, travel decision-making, as well as behavioral intention (Shafiee, Tabaeeian \& Tavakoli, 2016; Aldaihani \& Ali, 2018). One of the most traditional definitions for the concept of Destination image is "an expression of all objective knowledge, impressions, prejudices, imaginations and emotional thoughts an individual or a group have of a particular location" (Jenkins, 1999) .

On the one hand, the destination image was defined by Crompton (1979 cited in Ekinci, 2003) as: "the sum of beliefs, ideas and impressions a person has about a destination." A similar approach is Cai's (2002), who defines the image as "perceptions about a place reflected by existing associations in the mind of the consumer." Other authors supported the idea that the destination image is "an internalized, conceptualized and personalized understanding of what one knows" (Ahmed, 1996). Destination image is defined as "Perceptions or impressions of a destination held by tourists with respect to the expected benefit or consumption values" (Tapachai \& Waryszak, 2000).

Two most common components of destination image are cognitive and affective aspects, In general, cognitive evaluations refer to the collection of beliefs and knowledge that reflect by the perceived characteristics of a destination, while affective covering the feelings and emotions of tourists about a destination. Furthermore, some researchers argue the third component of destination: conative aspects, which is the action component of image such as visit/revisit intention or recommendation (Shafiee, Tabaeeian \& Tavakoli, 2016)

The overall image is obtained as the result of interactions between destination image components (Beerli \& Martı́n, 2004). According to previous investigations, an overall image is composed of cognitive beliefs (i.e. knowledge regarding to destination attitudes) and affective emotions (i.e. feelings toward the destination) and conative images are more likely to revisit a destination and recommend it to others (Kim \& Richardson, 2003). 


\section{Tourist Satisfaction}

Tourist satisfaction is considered one of the primary variables for sustaining competitive business in the tourism industry because it affects destination choice, product consumption and services (Kozak \& Rimmington, 2000). Tourist satisfaction has been one of the key areas of tourism research for more than four decades (Rajesh, 2013).

Oliver suggested the most influential definition of satisfaction (Prayag, Landré \& Ryan, 2012). According to this author, customer satisfaction is the result of evaluating the difference between customer expectations and received quality, Satisfaction is an assessment of tourist experience, once the obtained value outweighs price, time, and effort, customers become satisfied (Song, Veen , Li \&Chen , 2011).

Kotler (2000) defined satisfaction as “a person's feelings of pleasure or disappointment resulting from comparing a product are perceived performance (or outcome) in relation to his or her expectations". Kim et al., (2003) defined customer satisfaction "Is a post-purchase attitude formed through a mental comparison of the product and service quality that a customer expected to receive from an exchange."

Song, Van der Veen, $\mathrm{Li}$, and Chen (2011) also argue that satisfied tourists are valuable sources of information for satisfying potential tourists and play a vital role in tourism marketing. The concept of satisfaction has attracted considerable attention from scholars due to its positive impact on profits, loyalty, and repeat business in the future (Zeithaml, Bitner \& Gremler, 2013).

Different methods to measure customer satisfaction have been introduced, discussed and adapted. Generally, they can be classified into two main approaches: disconfirmation theory and performance only, the first one is based on the gap between expectations and perceived performances to determine satisfaction. However, some authors criticize the accuracy of this approach such as personal bias and problems with measuring expectations; the second approach is through the evaluation of destination's attributes, which researchers choose to establish their own model (Yüksel \& Yüksel, 2008).

\section{Attributes of Satisfaction}

Satisfaction attributes were analyzed by cognitive image of natural resources, cognitive image of service quality, cognitive image entertainment and affective image (Hernández, Solis, Miguel , Tena \& García, 2006). Satisfactions of tourist measured by general satisfaction attribute (attractions, accommodation, accessibility, amenities and activities) and met expectations. The satisfaction attributes included attractions, lodging, dining, shopping, accessibility, activities and events and environment (Qing \& Qu, 2008). Attributes like perceived attractions, perceived quality, perceived risk and perceived value used measure the satisfaction of tourists (Quintal \& Phau, 2008). Attributes like comfort facilities, safety \& infrastructure, cultural attractions \& shopping, tourist attractions \& ambience and variety \& accessibility affects tourist satisfaction Destination image, attitude, motivation, natural landscapes, service and recreational equipment were attributes which affects the tourist satisfaction (Alcocer \& Ruiz, 2019) .Attributes like travel environment, price or value, accessibility and natural attractions influence tourist satisfaction. Basic services, attractions and accessibility affect tourist satisfactions, Attributes like Recommendation destination to others, generate positive word of mouth and intention to revisit the destination (Eusébiom \& Vieira, 2013). Tourist attractions, basic facilities, cultural attractions, touristy substructures and access possibilities, natural environment, variety and economical were influence tourist satisfaction (Coban, 2012).

\section{Destination Loyalty}

Newman \& Werbel (1973) defined "loyal customers as those who re-buy a brand, Tellis (1988) defined it as "behavioral terms as repeat purchase frequency or relative volume of same-brand purchasing". Hawkins, Best \& Coney (1995) defined loyalty as "consumers' intentions or actual behavior to repeatedly purchase certain products or services". Oliver (1999) defined that tourists' 
loyalty is "a deeply held commitment to rebuy or re-patronize a preferred product/service consistently in the future", Destination loyalty, according Yoon and Uysal (2005), refers to a repeat visitation frequency or relative desire of same destination revisit.

Tourists' loyalty also considers a vital feature for destination marketers, because it is connected to a lot of desire with less cost, which includes keeping existing visitors rather than catching new visitors (Loureiro \& González, 2008). However, repeat tourists reduce the cost of marketing compared to attracting first-time visitors (Shoemaker \& Lewis , 1999).

Nowadays destinations face Strong competition amongst each other and it may become tougher in years to come. As such, marketing managers should understand reasons why tourists are faithful to destinations and what influences their loyalty (Campon \& Alves, 2013).

Marketing literature has revealed sporadic evidence that favorable image can contribute to loyalty For example, a study on store image revealed that formation of image helps predict store loyalty (Kandampully \& Zhang, 2015). An experimental study by Malhotra, (2004) indicated that attributes like comfort facilities, safety \& infrastructure, cultural attractions \& shopping, tourist attractions \& ambience and variety \& accessibility affects tourist loyalty (Prayag, 2008). Tourist loyalty depends on satisfactions of tourist (i.e. attractions, accommodation, accessibility, amenities and activities) and met expectations (Chia \& Qub, 2008), It should also be noted that destination loyalty depends on tourists' perception concerning the place and how potential tourists perceive of information given to them by those who have already visited (Yoon and Uysal, 2005), Thus for destination loyalty to be effective, destinations should create positive perceptions and image in the minds of tourists in order to affect Tourist Satisfaction.

\section{Structural Relationship between Destination Image, Tourists' Satisfaction and Loyalty}

Destination image comprises of various attributes which influences Tourist satisfaction. These attributes can either be controllable (price, destination product, promotion and place) or uncontrollable (destination characteristics) (Govers, Go \& Kumar, 2007). Tourism managers use these attributes to stimulate the positive perception of the destination (Currie, Wesley \& Sutherland, 2008). However, it is vital to understand potential tourists' expectations concerning the destination since it helps in creating positional strategies which are used to modify the image (Hsu, Tsai \& Wu, 2009).

Destination image affects tourists in the process of selecting a destination and planning their future visits. It also exercises a positive impact on quality and satisfaction. A positive destination image encourages more visits and hence greater customer satisfaction (Jang \& Feng, 2007). Tourist satisfaction drastically improves if the destination image is positive (Beerli \& Martín, 2004).

According to Chia and Qu (2008), destination image plays a positive impact on quality and satisfaction which subsequently impacts on tourists' behavioral intentions. A favorable image leads to higher chances to go back to the same place. Chi and Qu's model suggested that destination image is an antecedent of satisfaction. In turn, satisfaction positively influences destination loyalty. Their findings suggested that tourists' loyalty was increased by positive destination image and high level of satisfaction.

Destination image has a great influence on selection and tourists' perception in regard to destination. Image will affect destination selection process of tourists, post-selection evaluation of destination and whether they need to revisit the destination (Chia \& Qu, 2008). Destination image also impacts on tourists' behavioral intentions (Prayang, 2008). According to Lee (2005), destination image influences many consumers' behaviors like revisit intentions, and recommendations to others. Similarly Fuchs and Weiermair (2003) allege that a positive destination image influences tourist satisfaction and behavioral intentions of visitors.

Tkachenko and Sill (2011) researched on Russian tourists in Korea showed that destination image influenced how tourists were loyal to Korean tourism destination. Chen and Tsai's (2007) studied in Kengtin (Taiwan) indicated that image also has a crucial role in building destination 
loyalty; they showed that destination image greatly influenced the tourists to intent to revisit and recommend to others when they go back.

\section{Proposed Model and Hypotheses}

Drawing on the literature review, this study analyses The Impact of Destination Image on Tourists' Satisfaction and loyalty. In this research, the proposed model was developed based on previous studies that have shown that destination image is fundamentally influenced by the cognitive, affective and Conative components, i.e., On the satisfaction of the tourist then loyalty, the following conceptual model describe it (Figure 1).

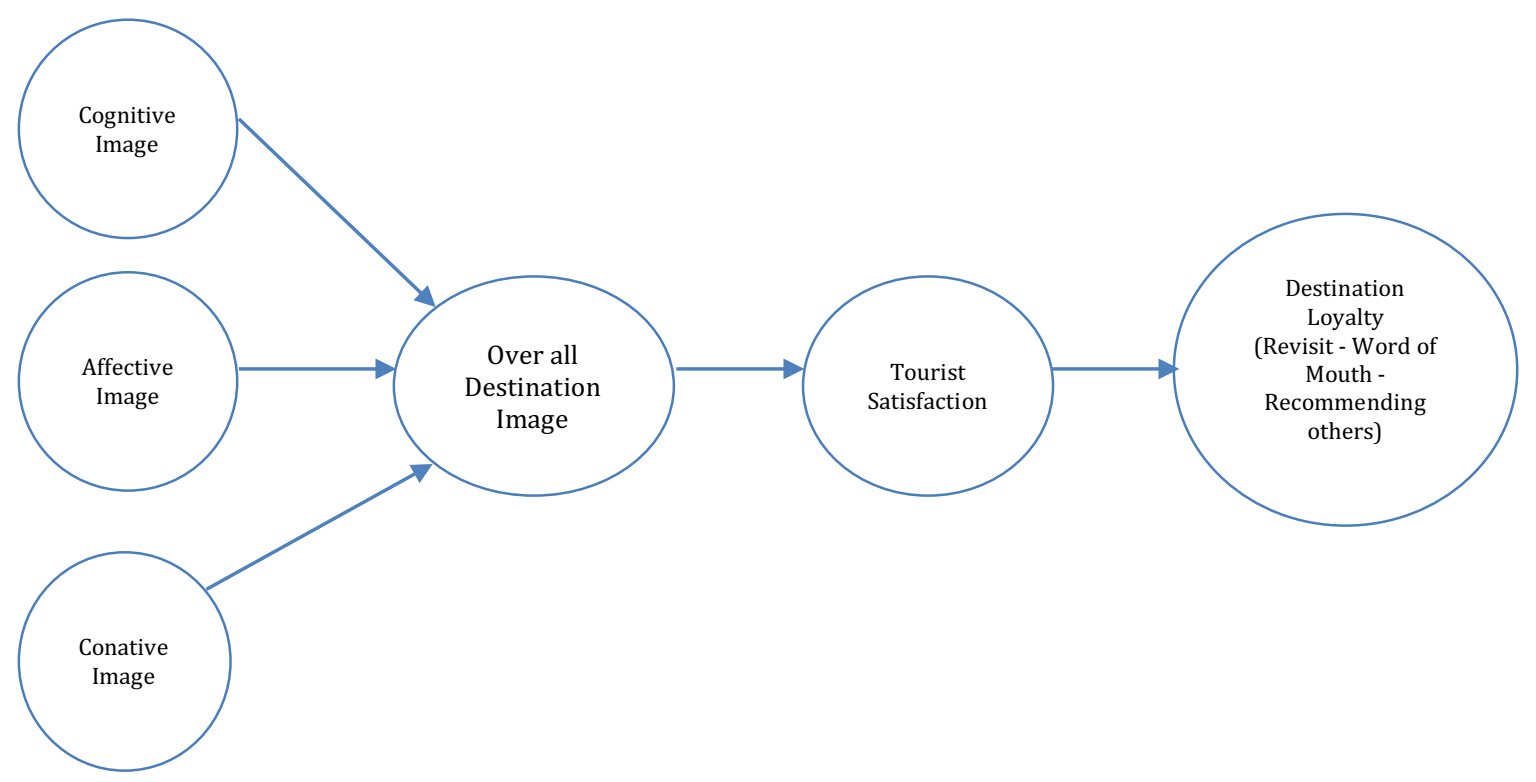

Figure 1: The Impact of Destination Image on Tourists' Satisfaction and loyalty

This part discusses the methodology used in gathering the necessary information in this study in detail and highlights the sources of data and research design as well as research sample. In addition to, the data analysis and results of the field study.

\section{Methodology}

This study has adopted a qualitative method, a qualitative research places emphasis upon exploring and understanding "the meaning individuals or groups ascribe to a social or human problem" (Creswell, 2014, p4). Qualitative research methods focus on discovering and understanding the experiences, perspectives, and thoughts of the participants" (Harwell, 2011). Hence, talking to people would be one of the most effective methods for attaining and exploring phenomena (Alshenqeeti, 2014).

\section{Research Sample}

Sampling is the process of identifying of an appropriate study population. It is important as it enables researcher to save time and labor and enables the researcher to deduce the characteristics of the whole population (May, 2001), the sample has been defined as a "subgroup of a population and using the data collected as research information" (Frey et al., 2000). Sample is also defined as "the 
subset of units that have been selected" (Molenberghs, 2010). "Sampling allows researchers to obtain a representative picture about the population, without studying the entire population" (Molenberghs, 2010), this research utilized convenience sampling method. Convenience sampling (also known as availability sampling) is a specific type of non-probability sampling method that relies on data collection from population members who are conveniently available to participate in study (Saunders, Lewis \& Thornhill, 2012).

Twenty tourists from (Finland, United Kingdom, United States and Egypt) were approached by the researcher and thus formed the sampling frame; these interviews were contacted via social networks like Skype, Facebook and Zoom App. Sample age ranges between 17 and 45 years, Approximately $85 \%$ of the sample had previously visited Egypt.

\section{Data Collection Tools}

The interview was invoked as a data collection tool and obtaining data by asking questions or discussing with sample participants, which involve face-to-face interaction , According to Kval (1996) An interview is "a conversation, whose purpose is to gather descriptions of the [life-world] of the interviewee" with respect to interpretation of the meanings of the 'described phenomena'.

There are three types of interviews, structured interviews where the interviewer asks a set of standard, predetermined questions about particular topics, in a specific order. Then semistructured interviews where the interviewer uses a set of predetermined questions and the respondents answer in their own words, based on these answers to supplementary questions are asked for clarification. Finally, unstructured interviews where the interviewer has no specific guidelines, predetermined questions, or list of options. The interviewer asks a few broad questions to engage the respondent in an open, informal, and spontaneous discussion (Mason, 2002). This research used structured interviews by conducting interviews with a group of tourists, in order to explore issues concerning the effect of destination image on their satisfaction and loyalty in Egypt.

The interview includes 10 questions, actually conducting personal interviews with a group of tourist, in order to explore issues concerning destination image about Egypt. Firstly, Identifies the effect of destination image on their satisfaction about Egypt. Secondly, Measures the impact of satisfaction on tourists' loyalty.

\section{Results}

As previously mentioned, one of the primary objectives of the study was to assess the image of Egypt as a destination and which of the aspects related to a destination have the greatest impact on the satisfaction and loyalty of tourists.

This part deals with analysis of information which was collected from interviews. Analysis is done qualitatively in regards to different interviewees who were involved in the interview process.

\section{Impact of Destination Image on Tourist Satisfaction towards Egypt}

According to reviewed literature, there exist various definitions about concepts of destination image and its effect on Tourist Satisfaction. Most of the interviewed Tourists said that the image that the destination portrays actually attracts them to visit. They said that satisfaction is derives from the image of the destination, the quality of services and diversity of attractions.

Interviewee A (Marketing Manager) stated that "her major aim of visiting Egypt was due to its variety attractions". This statement from interviewee showed that most visitors consider that the favorable image is derived from the variety of product offerings. Um, Chon \& Ro (2006), acknowledged that destination image influences tourists' perception, behavior and destination choice. Thus image influences tourists in choosing a destination, subsequent trip evaluation and their future intentions if they were satisfied by the image.

Another interviewee G (University Professor), stated that "her attraction towards Egypt and hence satisfaction stems from warm and friendly nature of citizen, She also said she was very satisfied with the efficiency of the services she got while visiting Egypt". Interviewee E (Chef) said 
that "Egypt is a fun and beautiful destination with warm and welcoming staff". Their statements describe what it make a destination to obtain a positive image, one of these factors are the highquality visitor care and treatment by administrators and staff. Their responses is in agreement with interviewee A (Marketing Manager)'s statement that "Egypt's atmosphere is warm and welcoming, Interviewee A also added that she is satisfied by the safety, which prompts her to make another visit in the future, but the worst thing in Egypt was the Jam traffic".

Interviewee F (Teacher) explained that "visitors are satisfied with the historic and architectural attractions of Egypt. He further supposed that Egypt is a comfortable and unique destination and that the locals are very welcoming, thus encouraging tourists to visit Egypt". Lee (2009) Introduced that destination image positively affects consumer behavior and hence the level of satisfaction, i.e., favorable image attracts visitors while bad image discourages them from visiting the place again future. Still, Bigne \& Sanchez (2005) posits that the image has a positive impact on the decision to stay and satisfaction, whereas perceived quality links the image they perceive of a destination and their satisfaction. If customers get positive value then they will be satisfied and if they get a negative value they will be dissatisfied.

Interviewee C (Restaurant Owner) outlined that "he feels a sense of excitement, and happiness because Egypt is extremely attractive, friendly and full of adventure". His response justifies interviewee G (University Professor) response that "the friendliness of local people, including pleasant staff and friendly atmosphere makes him get satisfied". Kotler, Bowen\& Makens (2006) established the following pattern: image-quality-satisfaction-post purchase intention. They postulated that image influences how consumers perceive quality; more positive image leads to higher perceived quality. Perceived quality will effect on the level of satisfaction of consumers.

Interviewee I (Accountant) stated that "Most foreign tourists are attracted with rich collections of Ancient Egyptian arts, she acknowledged that cheap online advertisement is the source of the favorable image that tourists have about Egypt". Pike \& Ryan (2004), state that Marketing strategies ensure that the picture of the destination is made known to various potential visitors so as to increase the chance of them visiting the place. This is supported by interviewee $\mathrm{H}$ (Tour Operator), who said that "Most tourists like to visit Egypt because of internet adverts and friends' reviews, so they perceive the destination as unique and attractive place, so making them want to visit".

\section{Impacts of Destination Image on Destination Loyalty towards Egypt}

Destination image literature ensures that the main aim of each tourist destination is to ensure that tourists become loyal. According to Yoon \& Uysal (2005), when tourists visit a particular destination more than once, this is tourist loyalty (Aldaihanin\& Ali, 2018). Chen \& Gursoy (2001) stated that when a tourist becomes loyal to a particular destination, he or she recommends others to visit that destination (Chen \& Gursoy, 2001). Accordingly, Yoon \& Uysal (2005) stated that if tourists get better treatment from a tourist destination, then they will be loyal towards that destination. Still, positive word of mouth concerning a destination means that the tourist has become loyal and likely to visit the place once again in the future.

When asked interviewees if they intend on visiting Egypt in the future, interviewee $G$ (University Professor) agreed to visit again. Interviewee E (Chef) said that "Egypt is more attractive than many other places because of its treasured and historic masterpieces, and that he plans to visit again in the future". Interviewee J (Student) said that "while the services she received in other destinations were attractive, Egypt's services far outpaced them, especially in terms of price and accommodation". Interviewee H (Tour Operator) explained that "customers of Egypt are extremely loyal since most of them recommended their friends to visit. When asked to describe Egypt", interviewee K (Student) stated that "it is a very attractive and unique location". Still, interviewee A (Marketing Manager) said that "she plans to revisit Egypt because she is completely attracted to it. Because she also found a big difference between Egypt and other places she had visited previously". According to her, Egypt, unlike other tourists' destinations she has been to, 
offers rich cultural and historical attractions, hence her loyalty to it. When interviewee G (University Professor) asked how he felt about Egypt, He said "he satisfied with that place and will tell his friends, and relatives to visit Egypt so that, they can experience for themselves how unique it is". Interviewee N (Relationship Manager), although he had not previously traveled to Egypt, he said "He really loves the place and hopes to visit it in the future". Yoon \& Uysal (2005) postulated that destination image positively influence attitudes of consumers and hence establishing destination loyalty. Still, the study carried out by Chen \& Tsai's (2007) in Kengtin (Taiwan) showed that image also has an important role in developing destination loyalty. They also showed that destination image greatly influenced the tourists to intent to revisit and recommend to others when they go back.

Interviewee $\mathrm{O}$ (freelancer) stated that "Egypt has fantastic attractions that are inspiring her to visit that place again. Despite traveling to other countries, she explained categorically that the services she enjoyed in Egypt were of high quality and made her feel fully fulfilled". This corresponds to interviewee B(Receptionist)'s point of view that "the loyalty of tourists towards Egypt makes them choose the place not only for tours, but also for social events such as weddings". Based on the two responses received, it is evident that both interviewees are very loyal to Egypt and thus talks positively concerning it. When asked about the specific feature that attracts her to Egypt, interviewee G (University Professor) stated that "Luxor and Aswan, Architecture and ancient Collections are aspects that makes her loyal towards Egypt, also The great experience with customer service also increases her loyalty", So If tourists get satisfied with certain or all aspects of a destination, and then they are more likely to visit the destination multiple times. They become loyal to destination and they spread positive word of mouth to their friends, families, and relatives (Chen \& Tsai, 2007; Yoon \& Uysal, 2005). It is a great success for any destination to make tourists loyal to them, since one loyal tourist helps to generate more revenue.

It is a common knowledge that customers are happy with high quality services, thus they become loyal (Aydin \& Ozer, 2005). Interviewee A (Marketing Manager) clarified that "she is happy with Egypt due to equal prices and good quality accommodation". According to Bigne (2005), service quality of a tourist destination positively impacts on tourists' overall satisfaction, leading to enhanced destination loyalty.

According to Chi \& Qu (2008), destination image has a positive impact on satisfaction which will hence impact on behavioral intentions of tourists. A positive image leads to higher chances to go back to the same place. Chi \& Qu's model explained that destination image is a prerequisite for satisfaction. In turn, satisfaction positively influences destination loyalty of tourists. Their findings suggested that tourists' loyalty was increased by positive destination image and high level of satisfaction. Recent researches have confirmed that revisit intention and positive word of mouth positively influence on the decisions of relatives and friends to visit a particular destination (Govers, Go, and Kumar, (2007).

\section{Limitations and Suggestions for Further Research}

This paper reported an attempt to assess the impact of destination image on tourist satisfaction and destination loyalty towards Egypt. Assessing the role and the formation of destination image has highlighted the need of distinct and unique image that attracts, satisfies tourists and enables them to develop loyalty. Moreover, this paper gave suggestions on how to boost Egypt's image as a tourist destination.

However, just like any other researches, some challenges have influence on the effectiveness and efficiency of this research. Firstly, this research was confined to a relatively small sample of interviewees and thus the images portrayed in this study do not accurately reflect Egypt's overall image. Secondly, the lack of funding implied that the research had to be carried out within the financial capability of the researcher. To overcome this financial challenge, the research used a small and a convenient sample size. To avoid the inaccuracy of data analysis, the researcher provided theoretical literature obtained from reviewed articles and books by various authors. 
This study is useful for tourism decision-makers in both the private and public sectors, and will provide advices for planning, marketing and development of appropriate resource allocation strategies. This study considered an effective application for destination promotion and positioning activities. This study can also be used as a powerful means of persuasion for addressing issues relating to tourism development in other tourism destinations.

\section{Conclusion}

The current study shows that destination image has indeed an impact on tourist satisfaction and loyalty in Egypt, offering a better insight into the relation between these concepts, by trying to determine which constructs have the most influence on tourists' satisfaction and their loyalty (intention of revisiting and recommending the destination).The results of this study on destination image and its impact on the satisfaction and loyalty of tourists in the context of tourism in Egypt can be useful to several categories. Firstly, Egyptian management organization should pay attention on building and strengthening a strong image of Egypt as a travel destination. Secondly, National authorities, as well as Destination Management or Marketing Organizations should take into account the issues raised by tourists as being deficient in Egypt as a tourism destination. For example, infrastructure one of the elements reported to be deficient in Egypt as a tourism destination. Authorities should take action on this issue because foreigners visiting our country may be reluctant to choose to visit Egypt if they do not have adequate road infrastructure to facilitate access to the destination. Secondly, the Destination Management organization in Egypt should take into account that tourists say they are satisfied when they have a wide range of services to choose from. Thus, Destination Management organization should execution development of tourist services that do not exist or are poorly developed in some Egyptian destinations. Moreover, the research revealed that for Egyptian tourists the quality of the human interaction within the destination has great importance. If the locals at a destination are hospitable to the tourists who arrive there, it might influence the quality of their stay and the tourists' intention to spend another holiday in the same place. Although locals may consider tourists responsible for overcrowding, rising prices or environmental destruction and therefore be less hospitable to them, they should also consider the positive effects that tourism brings to their community such as infrastructure development, economic growth, new job opportunities etc.

\section{References}

Ahmed, Z. U., (1996). The Need for the Identification of the Constituents of a Destination's Tourism Image: A Promotion Segmentation Perspective, Journal of Professional Services Marketing, 51(2), 44-57.

Alcañiz,E. B., García, I. S., \& Blas, S. S. (2005). Relationships among residents' image, evaluation of the stay and post-purchase behaviour, Journal of Vacation Marketing, 11(4), 291-302.

Alcocer, N. \& Ruiz, V., (2019). The role of destination image in tourist satisfaction: the case of a heritage site, Journal of Economic research-ekonomska istrazivanja, 4-6.

Aldaihani, F. M. F., \& Ali, N. A. (2018). Factors Affecting Customer Loyalty in the Restaurant Service Industry in Kuwait City, Kuwait. Journal of International Business and Management, 1(2), 1-14.

Aldaihani, F. M. F., \& Ali, N. A. B. (2018). Impact of Electronic Customer Relationship Management on Customers Satisfaction of the Five Stars Hotels in Kuwait. Global Journal of Management And Business Research. 18(5). 1-11.

Almeyda, M. \& Babu, P., (2017). The evolution of destination branding: A review of branding literature in tourism, Journal of Tourism, 3(1), 9-17.

Alshenqeeti, H., (2014). Interviewing as a Data Collection Method: A Critical Review, Sciedu Press, English Linguistics Research, 3(1), 39-45.

Ana C. \& Helena A., (2013). Loyalty Measurement in Tourism A Theoretical Reflection, Springer Heidelberg, New York, 13-40.

Asuncio B., \& Josefa M., (2004).Factors influencing destination image, Annals of Tourism Research, 31(3), 657-681. 
Atila Y., \& Fisun Y., (2008). Consumer Satisfaction Theories: A Critical Review. In: Tourist satisfaction and complaining behavior, Nova Science, New York.

Aydin, S. \& Özer, G., (2005). The analysis of antecedents of customer loyalty in the Turkish mobile telecommunication market, European Journal of Marketing, 39(7), 910-925.

Beerli, A., \& Martin, J.D, (2004). Factors influencing destination image, Annals of Tourism Research, 31(3), 657-681.

Beerli, A. \& Martín, J. D., (2004). Tourists' characteristics and the perceived image of tourist destinations: a quantitative analysis - A case study of Lanzarote, Spain,Tourism Management, 25(5), 623-636.

Cai, L. A., (2002). Cooperative branding for rural destination, Annals of Tourism Research, 29(3), $720-742$.

Celeste E., \& Armando V., (2013). Destination Attributes' Evaluation,Satisfaction and Behavioural Intentions: a Structural Modelling Approach, Annals of Tourism Research, 15(1), 66-80.

Ching-Fu, C. \& Chun, T., (2007). How Destination Image and Evaluative Factors affect Behavioral Intentions, Tourism Management, 28(4), 1115-1122.

Christina G. \& ChiHailin Q., (2008). Examining the structural relationships of destination image, tourist satisfaction and destination loyalty: An integrated approach, Journal of Tourism Management, 29(4), 624-636.

Chun-yang, W. \& Maxwel, K., (2010). The Relationships of Destination Image, Satisfaction, and Behavioral Intentions: An Integrated Model, Journal of Travel \& Tourism Marketing, 20(5), 575-595.

Creswell, J. W., (2014). Research Design: Qualitative, Quantitative and Mixed Methods Approaches (4th ed.), Sage Publications Ltd, London

Ahmed, Z. U., (1996). The Need for the Identification of the Constituents of a Destination's Tourism Image: A Promotion Segmentation Perspective, Journal of Professional Services Marketing, 51(2), 44-57.

Alcañiz,E. B., García, I. S., \& Blas, S. S. (2005). Relationships among residents' image, evaluation of the stay and post-purchase behaviour, Journal of Vacation Marketing, 11(4), 291-302.

Alcocer, N. \& Ruiz, V., (2019). The role of destination image in tourist satisfaction: the case of a heritage site, Journal of Economic research-ekonomska istrazivanja, 4-6.

Almeyda, M. \& Babu, P., (2017). The evolution of destination branding: A review of branding literature in tourism, Journal of Tourism, 3(1), 9-17.

Alshenqeeti, H., (2014). Interviewing as a Data Collection Method: A Critical Review, Sciedu Press, English Linguistics Research, 3(1), 39-45.

Ana C. \& Helena A., (2013). Loyalty Measurement in Tourism A Theoretical Reflection, Springer Heidelberg, New York, 13-40.

Asuncio B., \& Josefa M., (2004). Factors influencing destination image, Annals of Tourism Research, 31(3), 657-681.

Atila Y., \& Fisun Y., (2008). Consumer Satisfaction Theories: A Critical Review. In: Tourist satisfaction and complaining behavior, Nova Science, New York.

Aydin, S. \& Özer, G., (2005). The analysis of antecedents of customer loyalty in the Turkish mobile telecommunication market, European Journal of Marketing, 39(7), 910-925.

Beerli, A., \& Martin, J. D, (2004). Factors influencing destination image, Annals of Tourism Research, 31(3), 657-681.

Beerli, A. \& Martín, J. D., (2004). Tourists' characteristics and the perceived image of tourist destinations: a quantitative analysis - A case study of Lanzarote, Spain,Tourism Management, 25(5), 623-636.

Cai, L. A., (2002). Cooperative branding for rural destination, Annals of Tourism Research, 29(3), $720-742$.

Celeste E., \& Armando V., (2013). Destination Attributes' Evaluation, Satisfaction and Behavioural Intentions: a Structural Modelling Approach, Annals of Tourism Research, 15(1), 66-80. 
Ching-Fu, C. \& Chun, T., (2007). How Destination Image and Evaluative Factors affect Behavioral Intentions, Tourism Management, 28(4), 1115-1122.

Christina G. \& ChiHailin Q., (2008). Examining the structural relationships of destination image, tourist satisfaction and destination loyalty: An integrated approach, Journal of Tourism Management, 29(4), 624-636.

Chun-yang, W. \& Maxwel, K., (2010). The Relationships of Destination Image, Satisfaction, and Behavioral Intentions: An Integrated Model, Journal of Travel \& Tourism Marketing, 20(5), 575-595.

Creswell, J. W., (2014). Research Design: Qualitative, Quantitative and Mixed Methods Approaches (4" ed.), Sage Publications Ltd, London.

Çoban, S., (2012). The Effects of the Image of Destination on Tourist Satisfaction and Loyalty: The Case of Cappadocia, European Journal of Social Science, 29(2), 222-232.

Currie, R. ; Wesley, F. \& Sutherland, P., (2008). Going where the Joneses go: Understanding how others influence travel decision-making, International Journal of Culture. Tourism and Hospitality Research, 21(1), 12-24.

Del I. H., Roger J., \& Kenneth A., (1995). Consumer Behavior: Implications for Marketing Strategy. Sixth Edition, Richard D Irwin, Chicago.

Ekinci, Y., (2003). From destination image to destination branding: An emerging area of research, e-Review of Tourism Research (eRTR), 1(2), 21-24.

Enrique B., Isabel S., \& Javier S., (2005). Tourism Image, Evaluation Variables and After-purchase Behavior: Inter-relationship, Tourism Management, 22(1), 607-616.

Fuchs, M. \& Weiermair, K. (2004). Destination benchmarking: An indicator-system's potential for exploring guest satisfaction, Journal of Travel Research 42(1), 212-225.

Gallarza, M.G., Saura, L.G., \& García, H.C., (2002). Destination image: Towards a conceptual framework, Annals of Tourism Research, 29(1), 56-78.

Girish, P., Martin, L. \& Chris, R. (2012). Restaurant location in Hamilton, New Zealand: clustering patterns from 1996 to 2008, International Journal of Contemporary Hospitality Management, 24(3), 430 - 450.

Haiyan S., Robert V., Gang L., \& Jason C., (2011). The Hong Kong tourist satisfaction index. Annals of Tourism Research, 39(1), 459-479.

Harwell, M. R., (2011). Research Design in Qualitative/Quantitative/Mixed Methods. 2 ed., Thousand Oaks, Sage.

HERLE, A., (2018). The Impact of Destination Image on Tourists' Satisfaction and Loyalty in the Context of Domestic Tourism, MID Journal, 1(2), 14.

Jang, S. \& Feng, R., (2007). Temporal Destination Revisit Intention: the Effects of Novelty Seeking and Satisfaction, Tourism Management, 28(10), 580-590.

Jenkins, O. H., (1999). Understanding and Measuring Tourist Destination Images, International Journal of Tourism Research, 1(1), 1-15.

Joseph S. \& Dogan G., (2001). An Investigation of Tourists' Destination Loyalty and Preferences, International Journal of Contemporary Hospitality Management, 13(2), 79-85.

Joseph W. \& Richard A., (1973). Multivariate Analysis of Brand Loyalty for Major Household Appliances, Journal of Marketing Research, 10(4), 404-409.

Kandampully, J., Zhang, T. \& Bilgihan, A., (2015). Customer loyalty: a review and future directions with a special focus on the hospitality industry, International Journal of Contemporary Hospitality Management, 27(3), 36-48.

Kim, H., Richardson, k. \& Sarah L. (2003). Motion Picture Impacts on Destination Images, Annals of Tourism Research, 30(1), 216 - 237.

Kotler, P., (2000). Marketing Management. 10th ed., Prentice-Hall, New Jersey.

Kotler, P., Bowen, J. T., \& Makens, J. C., (2006). Marketing for Hospitality and Tourism. 7 ed., Prentice Hall, Upper Saddle Rive.

Kozak, M. \& Rimmington, M., (2000). Tourist Satisfaction with Mallorca, Spain, as an OffSeason Holiday Destination, Journal of Travel Research, 38(3), 260-269. 
Kval, S., (1996). Interviews: An introduction to qualitative research interviewing, Sage, Thousand Oaks.

Lawrence R., Carl H. \& Gary L. (2000). Investigating Communication: An Introduction to Research Methods. 2 ed., Allyn and Bacon, Boston.

Lee, T., (2009). A structural model to examine how destination image, attitude and motivation affect the future behaviour of tourists, Leisure Sciences, 31(3), 215-236 .

Loureiro, S., \& González, F., (2008). The importance of quality, satisfaction, trust, and image in relation to rural tourist loyalty, Journal of Travel \& Tourism Marketing, 25(2), 117-136.

Lucio, L., Magdalena, M., Radilla,S., Moliner,M. \& García,H. (2006) Tourism Destination Image, Satisfaction and Loyalty: A Study in Ixtapa-Zihuatanejo-Mexico, Tourism Geographies, 8(4), 343-358.

María M., Jorge E. \& Carmelo J., (2015). Economic valuation of tourism destination image, Tourism Economics, 21(4), 741-759.

Mason, J., (2002). Qualitative Researching. 1 ed., SAGE Publications, Printed in Great Britain by The Cromwell Press, London.

May, T., (2001). Social Research: Issues, Methods and Process, Open University Press, Buckingham.

Molenberghs, G., (2010). Survey Methods \& Sampling Techniques, Katholieke Universiteit Leuven \& Universiteit Hasselt, Belgium.

O'Leary, S. \& Deegan, J., (2005). Ireland's image as a tourism destination in France: attribute importance and performance, Journal of Travel Research, 43(3), 247-256.

Pike, S. \& Ryan, C., (2004). Destination Positioning Analysis through a Comparison of Cognitive, Affective and Connative Perceptions, Journal of Travel Research, 42(2), 333-342.

Prayag, G., (2008). Image, Satisfaction and Loyalty - The Case of Cape Town, An International Journal of Tourism and Hospitality Research, 19(3), 205-224.

Quintal, V. \& Phau, J., (2008). A structural approach towards perceptions and satisfaction of revisit intentions. Curtin University of Technology, Australia.

Rajesh, R., (2013). Impact of Tourist Perceptions, Destination Image and Tourist Satisfaction on Destination Loyalty, Revista de Turismo y Patrimonio Cultural, 11(3), 67-78.

Richard L., (1999). Whence consumer loyalty?, Journal of Marketing, 63(1), 33-44.

Robert, G., Frank M. \& Kumar, K., (2007). Promoting Tourism Destination Image, Journal of Tourism Research, 14(2), 234-256.

Ruiz,C., Alcocer, N., \& López, V., (2019). The role of destination image in tourist satisfaction: the case of a heritage site, Economic Research-Ekonomska Istraživanja, 3-5.

Saunders, M., Lewis, P. \& Thornhill, A. (2012) . Research Methods for Business Students, 6th ed. , Pearson Education Limited.

Schneider, I. \& Sönmez, S. (1999). Exploring the Touristic Image of Jordan, Tourism Management, 20(4), 539-542.

Shafiee, M., Tabaeeian, R., \& Tavakoli, H., (2016). The Effect of Destination Image on Tourist Satisfaction, Intention to Revisit and WOM: An Empirical Research in Foursquare Social Media, Reaserch gate, 7(16), 2-4.

Shoemaker, S. \& Lewis, R., (1999). Customer loyalty: The future of hospitality marketing, International Journal of Hospitality, 18(1), 345-370.

Tapachai, N. \& Waryszak, R., (2000). An examination of the role of beneficial image in tourist destination selection, Journal of Travel Research, 39(1), 37-44.

Tellis, G. J., (1988). Advertising exposure, loyalty, and brand purchase: A two stage model of choice, Journal of Marketing Research, 134-144.

TzuKuang, H., YiFan, T. \& HergHuey,W., (2009). The Preference Analysis for Tourist Choice of destination: A case study of Taiwan. Tourism Management, 30(2), pp. 288-297.

Um, S., Chon, K. \& Hee, Y., (2006). Antecedents of Revisit intention, Annals of Tourism Research, 33(4), 1141-1158. 
Yoona, Y.\& Uysalb, M., (2005). An examination of the effects of motivation and satisfaction on destination loyalty: a structural model, Tourism Management, 26(1), 45-56.

Zeithaml, V., Bitner, M. \& Gremler, D., (2013). Services marketing: Integrating customer focus across the firm, 7th Ed., McGraw-Hill, New York 